\title{
COORDinating ON LOWER PRICES: \\ Pharmaceutical Pricing \\ Under Political Pressure
}

\author{
Sara Fisher Ellison \\ MIT \\ and \\ Catherine Wolfram \\ UC Berkeley and NBER
}

July 2004

This paper investigates possible effects of political activity on pharmaceutical prices, focusing on the health care reform period. We characterize firms based on their vulnerability to future price regulation and find that the more vulnerable firms were more likely to take various actions to forestall regulation, most notably coordinating on a specific percentage price increase during 1993. Since moderating price increases could have been an effective tool to avert regulation, the coordination we observe is the obvious response of the industry to a classic collective action problem.

\footnotetext{
*sellison@mit.edu, wolfram@haas.berkeley.edu. We are grateful to Shigeo Hirano, Nada Mora, Jie Shen, and Jeff Wilder for excellent research assistance. The first author acknowledges financial support from Eli Lilly through their grant to the NBER, the Hoover Institution, the Institute for Advanced Study, and the NSF (Grant SES-0219205). The second acknowledges financial support from the NSF (Grant SBR-9810402). Matthew Barmack, Ernie Berndt, David Cutler, Glenn Ellison, Zvi Griliches, Wally Mullin, Steve Puller and Mike Whinston provided valuable comments and suggestions.
} 


\section{INTRODUCTION}

Pharmaceutical prices have been a prominent political issue over the past two decades, surfacing everywhere from the Catastrophic Health Insurance Bill to proposals for Medicare coverage of drugs. During health care reform discussions in 1993, large-scale efforts to curb drug prices were debated and seemed likely to be enacted, but, in the end, were not implemented. Our purpose is to look for effects of the political climate on pharmaceutical firms' actions during this period. Using two different data sets, we find evidence of the more vulnerable pharmaceutical companies distorting price increases during the early years of the Clinton Administration, possibly altering their price increases to forestall potential regulation. In addition, we find evidence that firms colluded on specific price increases when political pressure was at its peak.

Economic models deal extensively with firms' responses to the legal environment in which they operate (i.e. past government actions) as well as their customers' and competitors' actions. This paper addresses the hypothesis that firms' decisions are also affected by pressure from the general public and policy makers, in other words, by the threat of future government action. Economists have proposed several theories to explain government involvement in firms' decisions. Public interest theories of industrial policy predict that the government will intervene to correct market failures. If government intervention is costly, however, the role the government plays in solving different market failures may vary based on the costs of intervention (or "political transaction costs"). In other words, in circumstances where the costs of government intervention are high and the costs of private action are low, there is room for private exchange (see Noll, 1989 and the references he cites).

Whether government regulation of drug prices would have solved a market failure is a complicated, controversial question on which this paper remains agnostic. Other theories of government regulation do not start from the premise that the government is solving market failures, but rather emphasize the roles that competing interest groups play in convincing policy makers to allocate rents to their members (Stigler, 1971). Within this paradigm, however, competing interest groups may still privately decide to effect changes to redistribute rents instead

of leaving decisions to policy makers. They may do so if the private steps are less expensive than 
potential policy changes. For instance, the drug companies could have lowered vaccine prices in 1993 in order to diffuse the strength with which children's rights activists opposed high prices if doing so avoided costly government intervention. Private responses are likely if they sufficiently diffuse the poignancy of the competing interest group's issue. One could even imagine a type of political "contestability," where the persistent threat of government intervention constantly distorts firm behavior.

This paper seeks to provide an empirical example of a case in which firms perceived that taking costly steps on their own was preferable to likely government intervention. Little empirical evidence of such actions yet exists. A related paper by Erfle and McMillan (1990) considers oil prices during the price shocks in the late 1970's, comparing prices charged by large, domestic oil producers to prices of small and foreign companies. They argue that the large domestic firms were better able to influence government and public perceptions about policy, and then they show that these large firms were more likely to adjust their prices for home heating oil relative to the prices for oil sold to electric utilities when evening television programs were providing heavy coverage of the oil price shock. Pricing during less politically sensitive times was more homogenous. Both Erfle and McMillan (1990) and our paper identify politically motivated pricing by comparing decisions across firms, although the approaches are complementary. While they segment firms as being more and less able to influence the government, this paper compares pricing by firms more and less willing to sacrifice current profits to avert future regulation. ${ }_{\text {. }}$ Olmstead and Rhode (1985) describe a situation where oil companies appeared to lower prices in the summer of 1920 in the face of potential government involvement, but conclude that the hypothesis is "nearly impossible to test" (p. 1050). In more recent work, Stango (2000) reports that bigger, more politically visible, credit card issuers were more likely to lower interest rates following threatened legislation to cap rates. He also shows

\footnotetext{
${ }^{1}$ The context studied in this paper is also slightly cleaner than Erfle and McMillan's because the period when political sensitivity was high was a function of a number of economy-wide factors that influenced the rise and fall of the health care reform debate. Erfle and McMillan have to address the fact that television news coverage may not be an exogenous measure of political awareness of oil prices if coverage is influenced by the level of or changes in oil prices.

${ }^{2}$ Both willingness and ability to influence government action should be important in determining which firms act, but an implicit assumption of our approach is that there are negligible differences in the abilities of brand name drug manufacturers (all fairly large and visible) to influence government actions.
} 
that announced rate reductions led to positive stock price responses for both the announcing firm and its competitors. The literature on firms' environmental activities also has examples of private responses to threatened regulation, and work on firms' responses to the threat of antitrust enforcement is closely related. 4

We are unaware of any other papers on regulatory threat that have documented a collective action response, though other work has empirical tests of tacit collusion in separate contexts. 5

Our results also speak indirectly to the nature of corporations' political power by providing a new piece of evidence on the way in which firms can set the political agenda. Previous empirical work has considered the impact of corporate lobbying and campaign contributions on political decisions. Studies have both sought patterns in campaign contributions (e.g. across industries) and also considered the relationship between campaign contributions and votes in Congress. By considering whether firms make decisions in response to the threat of policies, our results address the extent to which firms can keep issues from coming to vote in the first place. That would imply that by only considering actual votes, previous studies might have yielded biased assessments of corporations' impact on political outcomes.

Pharmaceutical prices have attracted considerable research interest, in addition to the attention they have received in public forums and the press. For instance, the systematic new product introductions (both generic and new branded) provide interesting test cases for theories

\footnotetext{
${ }^{3}$ Examples include Kennedy, Laplante and Maxwell (1994), Konar and Cohen (1997) and Maxwell, Lyon and Hackett (2000).

${ }^{4}$ Block, Nold and Sidak (1981), for instance, find a negative relationship between various proxies for the threat of antitrust enforcement and markups in the bread industry.

${ }^{5}$ For instance, Knittel and Stango (2003) show how nonbinding price caps serve as a focal point for tacit collusion, and Porter and Zona $(1993,1999)$ provide evidence of tacit collusion in procurement auctions.

${ }^{6}$ See, for example, Esty and Caves (1983), Masters and Keim (1985) and Grier, Munger and Roberts (1994).

${ }^{7}$ Since health care reform legislation failed for a number of reasons (see Johnson and Broder, 1996), the particular case we consider is not an ideal example of this part of the process. Other regulatory changes are more piecemeal and, therefore, more prone to the effects we describe.
} 
of market dynamics (see e.g., Caves, Whinston and Hurwitz, 1991, and Ellison and Ellison, 1999) and price indices (see e.g., Griliches and Cockburn, 1994). The industry is also heavily regulated along several dimensions, and a number of existing studies evaluate the effects changes in specific regulations have had on drug pricing (see e.g., Masson and Steiner, 1985, Grabowski and Vernon, 1992 and Scott Morton, 1997). Those studies consider enacted legislation and address neither the genesis of the regulatory changes nor the effects drug companies' actions may have had on the legislative outcome.

This paper proceeds by providing a chronology culled from the contemporary press of events, perceptions, and debates relevant to pharmaceutical pricing leading up to the first half of the Clinton Administration. Section 3 describes the two pricing data sets we use. The first contains Average Wholesale Prices (AWP), essentially the wholesale list price, of 106 of the largest revenue prescription drugs sold in the U.S. during the period, and the second contains wholesale transactions prices of antibiotics. There are fifteen antibiotics in the first data set, so we also compare pricing patterns for the drugs in common to the two data sets.

The main empirical work in the paper is presented in Section 4. It begins with overall time series patterns in pharmaceutical pricing and R\&D expenditures. These patterns are consistent with firms distorting prices to forestall regulation, although these changes could have been caused by a number of other factors. In order to identify the effects of political pressure on firms' actions, we then characterize firms by their vulnerability to regulation, based on two measures: the proportion of their drug portfolio which is typically sold to the elderly and the sales-weighted average remaining patent life of their drug portfolio. We find that the more vulnerable firms, as measured by our two variables, were more likely to engage in a variety of actions to forestall potential regulation, such as increasing political contributions and coordinating on a common price increase. In addition, since we have data on two different prices, AWP and transactions prices, we can track how coordination on AWP affected actual transactions prices.

During this period, the Pharmaceutical Manufacturers Association (PMA), the industry trade group, submitted a request to the Department of Justice (DOJ) requesting exemption from the 
antitrust laws to enforce an agreement among member companies to hold price increases at the rate of inflation. The DOJ eventually rejected the request, so the evidence of collusion is somewhat surprising. We also rely on documents submitted with the request to provide a backdrop to the companies' motivations for wanting to hold price increases down.

\section{CHRONOLOGY}

A public discussion about the need for health care reform had started to gain momentum around 1990, with prices of prescription drugs at the center of the discussion. Concerns over prices prompted Merck \& Co. to announce voluntary price restraints (amounting to a pledge not to raise prices faster than inflation) in 1990 and to publicly scold its competitors for large price increases in 1991. Merck's CEO Roy Vagelos says, "It is clear that the U.S. public and our congressmen and senators are focusing on health-care costs.... People are really concerned... and drug prices are such an obvious target" (The Wall Street Journal, 1991). (As we discuss below, several other leading manufacturers joined Merck's voluntary price restraints a few years later in the midst of the Clinton health care reform debate.)

Harris Wofford, running on a health care reform platform for a vacated Senate seat in 1991, won the election, setting the stage for the 1992 Presidential campaign, squarely focused on health care reform. ${ }^{8}$ In September of 1992, then-candidate Clinton gave a speech at Merck discussing the need for reform but offering few specifics. The speech was generally well received by the industry. After Hillary Rodham Clinton was appointed the head of the Health Care Task Force in January of 1993 and leaks about the Task Force's attitude toward drug prices surfaced later in the spring of 1993, prospects for the pharmaceutical industry dimmed significantly.

As part of a plan to transform the cost and delivery of health care, the Clinton Administration has launched a scalding attack on drugmakers, fanning public outrage over their high prices. The presidential task force, headed by Hillary Rodham Clinton, has threatened to shackle the industry with price controls and other onerous regulations. (Fortune, 1993)

\footnotetext{
${ }^{8}$ Much of the chronology and discussion of health care reform in the Clinton Administration is based on The System by Johnson and Broder.
} 
The prospects of the industry are reflected in a huge decrease, over $40 \%$ by one measure, in the market-adjusted value of a portfolio of pharmaceutical stocks over the year during which the health care reform plan was being formulated. The most precipitous decline occurs in the spring months, after leaks about price controls.

In March of 1993 several pharmaceutical companies announced voluntary price restraint, essentially keeping price increases at the rate of inflation (The San Francisco Chronicle, 1993). The Task Force disbanded at the end of May, and in September of 1993, the President's Health Security Plan was first leaked and then officially unveiled before Congress. The plan did not include price controls for pharmaceuticals. Instead it proposed to control costs of pharmaceuticals by giving the purchasers more "buying clout."

Under reform, with the addition of prescription drug coverage, Medicare will become the world's largest purchaser of drugs. And the Medicare program will use its negotiating power to get discounts from the pharmaceutical companies. In addition, with competing health plans trying to become more efficient, more and more buyers will use the same successful negotiating techniques. (The President's Health Security Plan, 1993)

October of 1993 marked the high point for the political prospects of health care reform (Johnson and Broder (1996)). The demise of the Clinton Plan was gradual, beginning soon after its official unveiling, continuing with announcements of various business and consumer interest groups that they would oppose it, and culminating with the official tabling of the legislation in September of 1994.

From the fall of 1992 through the fall of 1994, Congress was occupied first with the election and then with hearings on health care reform. Not surprisingly, there were no substantial legal changes enacted at the federal level involving pharmaceuticals during this period.

\footnotetext{
${ }^{9}$ See Ellison and Mullin (2001).

${ }^{10}$ For example, The Business Roundtable announced opposition to the plan in February.

${ }^{11}$ Ellison and Mullin (2001) provide a more complete argument that the health care reform debates were by far the most important event affecting pharmaceutical companies during this period.
} 


\section{PRICING DATA}

For our analyses we use two main pricing data sets. One is a set of 106 of the largest revenue prescription drugs sold in the U.S. during this period. These drugs span many different therapeutic classes and were all produced by "branded" manufacturers, those engaging in efforts to discover, patent, and sell novel pharmaceutical products. These are also the manufacturers receiving the most political scrutiny and pressure during health care reform discussions. These data contain monthly prices from 1989 to 1996, but do not contain information on sales or revenues. The second is a set of (virtually) all prescription antibiotics sold in the U.S. from 1990 to 1996 . These data have the obvious drawback of only covering one therapeutic class, but they do contain revenue information as well as information on sales by "generic" manufacturers and sales of other small revenue drugs. In addition, these sales data are reported separately by type of purchaser, such as hospital or drugstore. The other main difference between the two data sets is that the former contains Average Wholesale Prices (AWP), a sort of list price, as reported by the manufacturers, and the latter contains averaged transactions prices, as collected from both manufacturer and wholesale purchaser by IMS, a market research firm. These transactions prices are typically the result of negotiated discounts off of AWP.

Note that both of these data sets contain measures of wholesale prices, arguably the level of most interest in this market. Much of the public debate, centering on the actions of the drug manufacturers, is focused on the wholesale level. Government policies regarding drug reimbursement also are concerned with wholesale prices.

Our use of two separate data sets is an important feature of our study. AWPs are reported and published and tend to receive a lot of public scrutiny. AWPs, therefore, are an obvious tool for firms to use if they want to change prices in a visible way. Transactions prices are not typically publicly available, so changes in them might not be as politically salient, but they are obviously important as well because they are the actual wholesale prices paid and determine the final retail price of these drugs. We, therefore, look both for firms' reactions to political pressure in the list prices and how that reaction filters through to transactions prices. 
More detail on the structure and sources of these data sets, and on why we selected them, is included in the appendix. Two matters bear mentioning in the text. In both data sets, we have monthly observations at the presentation level. $\stackrel{12}{2}$ We choose to aggregate across both these levels. First, all of the analyses below will focus on price changes over six-month periods: Price Change $=\left(\left(p_{t}-p_{t-6}\right) / p_{t-6}\right)$ where $t$ is either April or October and $t-6$ is the October or April six months previously. It is sensible to do this for the AWPs in the top 106 data set because price changes are infrequent. For $91 \%$ of the observations at the monthly level, price changes are equal to zero, and the typical presentation in our data changes its price every 10 months. At the monthly level, $25 \%$ of the price changes are between December and January, so the October to April six-month change is less likely to be zero. We use 6-month price changes in the antibiotic data set for consistency with the other data set, and because we suspect that month-to-month changes reflect changes in the composition of buyers in a given month, so aggregating up to a longer period helps wash out this noise. We use April and October as endpoints so that the 6month period ending October 1993 corresponds to a period when the DOJ was reviewing a request from the pharmaceutical industry trade group to allow price coordination. For the AWP data set, we have data on 15 six-month periods between April 1989 and October 1996. For the antibiotic data set, we have data on 10 six-month periods between April 1991 and April 1996.

Second, we use presentation level data for the top-106 data set and drug-level data for the antibiotics data. We aggregate up to the drug level in the antibiotics data by weighting each presentation by the quantity sold. We lack presentation-level sales data for the top-106 data set, so any aggregating would be a strict average across presentations. Since price increases vary within a drug by presentation, averaging would mask attempts to coordinate since companies appeared to coordinate on some but not all presentations. For the antibiotics data, price changes at the presentation-level data are already noisy because, for instance, they reflect variations in the types of customers that purchased drugs in a given month, so averaging does not create the same problem.

\footnotetext{
${ }^{12}$ A presentation identifies a unique strength, dosage form, and package size of every drug.
} 
Table 1 presents summary statistics on price changes in the two data sets as well as on covariates that we use in our pricing equation below. For the top 106 drugs the average sixmonth growth rate was over $2 \%$, though the standard deviation of $3.4 \%$ suggests there was significant variation over time and across NDCs. Average growth rates are much smaller for the antibiotics data set, suggesting six-month growth rates of .26\%, although the standard deviation is $11 \%$. The lower average growth rates for antibiotics, which is not an artifact of the outliers, may reflect the fact that the antibiotic market is relatively saturated compared to other drug classes, making price increases more difficult. The antibiotics are also on average older than the top 106 drugs, and have only half-a-year remaining on their patents compared to over 5 years for the top 106 drugs.

Because there are 15 drugs that are common to both data sets, we compared the pattern of price changes on these drugs. To do this, we calculated presentation-level price changes and then formed an unweighted average across presentations of the same drug. ${ }^{2 .}$ The top half of Table 2 presents summary statistics on the 15-drug subsets of the two data sets, limited to the sample period for which we have prices in both data sets (October 1990-August 1996). In the first column, we report six-month price changes, calculated from October to April and April to October of the previous year. Notably, even when we have limited the sample to the same sets of drugs, the average monthly growth in wholesale prices is more than four-times faster than growth in transaction prices, suggesting that the discounts are not a fixed fraction of AWP. Price changes in the two data sets have similar standard deviations, suggesting, not surprisingly, that the transaction prices have higher coefficients of variation.

The bottom half of Table 2 reports correlations between drug price changes reflected in the two data sets. We report the overall correlation and a correlation in the variables net of the average price increase by drug. There is considerable heterogeneity in the correlations by channel: changes in the prices of drugs sold to federal facilities appear to track changes in AWP much less than changes in the prices of drugs sold to drugstores. Plots of the price series over

\footnotetext{
${ }^{13}$ While both data sets have observations available at the presentation level, there is no straightforward correspondence between the presentation identifiers in the two data sets.
} 
time indicated that the changes in the transaction prices often lagged changes in AWP by a month, so it is not surprising that the one-month correlations calculated but not reported here are lower. Overall, the large difference in the means of price changes in the two data series suggests that transaction prices are not simply a fixed percentage reduction off AWP, but the correlation in the price changes suggests that AWP captures many short- and medium-term changes in transaction prices.

\section{ANALYSIS AND RESULTS}

\section{Overall Trends}

A look at the aggregate time series data on both pharmaceutical pricing and pharmaceutical R\&D spending reveals interesting trends. Figure 1 plots annual changes in the CPI and PPI for pharmaceutical products, as well as the average annual price change across drugs in both our top 106 and antibiotics data sets. For comparison purposes, we also include the overall CPI. The slowdown in price growth in the early 1990's is pronounced in all price series, and it is most dramatic between 1992 and 1993, the period of the most serious health care reform discussions.

Figure 2 plots the weighted-average ratio of R\&D to sales for the 15 companies in our sample for which we could get both $R \& D$ and sales data for the entire eleven-year period from 1986-1996. ${ }_{4}^{4}$ Again, the period around health care reform is unusual. The graph demonstrates that the deceleration in $R \& D$ expenditure growth during health care reform exceeded the sales slowdown. This could suggest that the companies foresaw some chance that prices for new drugs would be regulated in the future, so they had less of an incentive to invest in drug development.

\footnotetext{
${ }^{14}$ The R\&D and sales data are from Compustat. Data for G.D. Searle and Sandoz were unavailable. Data for 6 companies were only available for part of the time period, and we exclude those companies from the figure so that year-to-year changes do not reflect compositional changes. When we include them, the dip in R\&D/Sales growth in 1994 is more dramatic and the change in 1996 is positive even though none of the composition changes occur during either of those two years.
} 
While these series are suggestive of an industry response to political pressure, they are also consistent with other, perhaps structural or demand-driven, changes in the industry. We, therefore, proceed by first characterizing differences in firms' sensitivity or vulnerability to regulation and then considering whether differences in various actions firms took appear to be related to these cross-sectional differences in sensitivity.

\section{Measuring Political Sensitivity}

To develop estimates of a company's sensitivity to the political climate, we appeal to Glazer and McMillan (1992) who propose a theoretical model of a monopolist facing future regulation. They demonstrate that the firm's incentives to reduce its prices in the face of potential regulation are a function of both the effect such an action has on the probability of regulation and the cost of sacrificing short run profits to avert regulation - the firm's discount factor. ${ }^{15}$ Based on this theoretical framework, we develop the following firm-level measures of the expected costs of future regulation:

Measure 1: A revenue-weighted average of the length of time remaining on a firm's patents, and

Measure 2: The percent of a firm's revenues derived from sales to the elderly.

Measure 1 is intended to proxy for the firm's discount factor, under the assumption that a firm with less time remaining on important patents would be less willing to take costly steps in the short run to preempt future regulation. Measure 2 captures the fact that firms with more drugs used by the elderly faced a higher probability of facing regulation in the near term since Medicare reimbursements would have provided a ready vehicle through which the government could affect drug prices. For instance, the most overt regulation of drug prices called for in the Clinton

\footnotetext{
${ }^{15}$ Baron (1997) develops a common agency model where two firms attempt to influence government decisions (in his case Kodak and Fujifilm are both trying to influence the Japanese and American governments). Though Baron's setting is somewhat different from Glazer and McMillan's (for instance, he has firms making direct expenditures to influence the government rather than using prices), the characterization of multiple firms taking actions to influence the government is appropriate to the pharmaceutical industry. A number of Baron's comparative static results are similar to those in Glazer and McMillan. For instance, he shows that a firm will spend more to influence the government if its payoff from doing so is higher.
} 
reform package was the proposal to prohibit Medicare reimbursement for new drugs deemed to be priced "too high." To the extent that the elderly are a more cohesive and powerful political faction than other drug consumers, Measure 2 could also capture a firm's incentive to influence potential regulation. 16

The variables we use to capture these two political sensitivity measures are presented in Table 3. Firm Patent Duration is the sales-weighted average of the time left on a company's patents as of 1993. In 1993, the average company in our sample had almost six years left on its typical patent, though there is a fair amount of variation across companies. 7 irm Elder Drugs measures the sales-weighted fraction of a company's drugs in therapeutic classes that are consumed primarily by the elderly. On average, companies sell 36 percent of their drugs in elder categories. The assumptions and data used to construct Firm Patent Duration and Firm Elder Drugs are described in the Appendix.

\section{Political Contributions}

Many instruments are available to firms who would like to influence political outcomes. Perhaps one of the most obvious is political contributions. The third column of Table 3 reports information on the growth in the amount each company's corporate PAC disbursed between 1991/2 and 1993. It is based on information reported to the Federal Election Commission and is not applicable for three companies. Neither Bayer nor Hoechst-Roussel had a corporate PAC during the time period considered, and Zeneca's PAC was not organized until the middle of 1993.

It would not be surprising, of course, to learn that companies had political motives when contributing to their corporate PACs, and, in particular, that more politically sensitive firms

\footnotetext{
${ }^{16}$ Maxwell, Lyon and Hacket (2000) develop a model where firms facing consumers with low political organizing costs would lower prices more to preempt regulation.

${ }^{17}$ We also collected data on the ratio of R\&D to sales by company. This is negatively correlated with Firm Patent Duration, perhaps indicating that firms with few remaining good patents are spending more (relative to sales) on developing new drugs.
} 
contributed more. We look, therefore, at the relationship between our political sensitivity measures and corporate PAC contributions as much as a check on our measures as anything else. The values of Firm Patent Duration and Growth in Company PAC are quite positively correlated. The correlation coefficient for the values is 0.80 and the coefficient for the dummy variables indicating whether or not the value is above the median is 0.39 . This correlation indicates that the more politically sensitive firms, using the patent duration measure, ramped up their PAC contributions more than less sensitive firms. By contrast, Growth in Company PAC is negatively correlated with Firm Elder Drugs $(\rho=-0.38)$. If Growth in Company PAC reflects the extent to which a company took political action in response to the impending threat of regulation and Firm Patent Duration and Firm Elder Drugs attempt to proxy for the different reasons a company would be sensitive, this suggests that Firm Patent Duration is a better measure of sensitivity.

Of course corporate PAC contributions are only one of many ways in which companies can make political contributions. For instance, individual company employees can contribute to PACs and directly to political candidates. If the individuals are executives, contributions may be implicitly tied to preferences on policies that affect the company. Unfortunately, it is extremely difficult to track such donations. The Center for Responsive Politics (see Makinson and Goldstein, 1994), provides aggregate statistics on the percent of contributions each industry makes through corporate PACs as a fraction of total contributions. According to their calculations, 76 percent of pharmaceutical manufacturers' contributions were through corporate PACs. We, therefore, feel that our measure captures the bulk of the political contributions.

\section{Joining the Price Pledge}

If a multi-firm industry is to take actions, such as lowering prices, to avert regulation, it must overcome the incentives individual firms face to free ride. In a highly concentrated industry, individual firms may calculate that the benefits of averting regulation for the whole industry outweigh the unilateral costs of lowering prices. Erfle and McMillan (1990), for instance, use the observation that big firms should have more of an incentive to unilaterally 
reduce prices than small firms as an identifying assumption. It is unclear whether the pharmaceutical industry was concentrated enough for individual firms to be willing to make substantial unilateral concessions. While individual drugs can have substantial market power, the industry overall is not concentrated. For instance, in March 1993, the Pharmaceutical Manufacturers Association (PMA) claimed that, "more than 20 companies' dollar sales must be included to reach a 75\% share of the market" (Ferguson, 1993). The other way for firms to overcome free ridership is to pledge to act collectively in the face of potential regulation.

Recall that in 1990, Merck made a public pledge to keep drug increases at or below the rate of inflation. No other major pharmaceutical firms joined in the pledge at that time. During health care reform discussions in 1992 and 1993, though, Merck renewed its pledge, and this time others followed. On March 12, 1993, the PMA, the industry trade group, submitted a request for a business review letter to the Department of Justice asking for exemption from the antitrust laws to enforce a voluntary program among their members to maintain price increases at the rate of inflation (Ferguson, 1993). By the time the PMA submitted the request, nine companies, including Merck, had unilaterally made pledges to keep price increases at or below increases in inflation. Six of these companies are in our data set. A March 14, 1996 Federal Trade Commission document concerning an investigation of the pledge as a means of price fixing identified an additional twelve firms who made price pledges over the course of 1993. Five of the firms in our data set were not identified on the FTC document. The last column of Table 3 indicates which firms were among these various groups.

There is no significant correlation between either whether a firm pledged or the timing of its pledge and Firm Patent Duration, but there is some relationship between pledge status and Firm Elder Drugs. Coding the firms that did not pledge as fours, we calculated the Spearman rank correlation between the pledge category listed in Table 3 and both political sensitivity variables. It is .14 for Firm Patent Duration and -.32 for Firm Elder Drugs, though in neither case can we reject that the variables are independent. Ignoring the differences in pledge timing, however, firms that did pledge had significantly higher values of Firm Elder Drug and insignificantly lower values of Firm Patent Duration. Given the high correlation between Firm 
Patent Duration and Growth in Company PAC, this could suggest that firms used pledging and campaign contributions as substitutes. It could also suggest that our indications of whether firms pledged were noisy.

The PMA's request to the DOJ cited the threatened regulation and was described as a temporary measure that would be disbanded if the Clinton Administration's Managed Competition plan were adopted. Notably, the request did not specify what would happen to the policy in the event the Clinton health care package failed. In response to questioning from the DOJ about why a formal agreement was needed if firms had pledged unilaterally, the PMA cited the benefits of having a formal coordinated policy over relying on firms' unilateral pledges. These included independent auditing and policies for dealing with firms that deviated from the policy. On October 1, 1993, the DOJ issued a letter denying the PMA's request.

\section{Coordination in List Prices}

While this episode suggests that pharmaceutical companies wanted to coordinate prices, the fact that the DOJ rejected the request would seem to suggest no actual coordinated pricing occurred. Empirical evidence in our data set suggests otherwise. Figure 3 plots the distribution of non-zero six-month price changes in the AWP data set. The six-month interval ending October 1993 coincides with the time period when the DOJ was reviewing the PMA request. Coordination during this interval is striking: over half (or 82/162) of the non-zero price changes were between $4.15 \%$ and $4.25 \%$. 18 here are other mass points during other six-month periods, though few of them are as dense as the massing at $4.2 \%$ in October 1993 . 19 Also, before October 1993, massing was more likely at round price increases, such as 5.0\%.

\footnotetext{
${ }^{18}$ For most but not all of the drugs with price changes at $4.2 \%$, the company used this increase for all of its presentations. Each of the companies that used $4.2 \%$ had at least one drug in our data set for which they used a different increase.

${ }^{19}$ Figure 3 was drawn with bins that were .1\% wide and centered around $.10 \%, .20 \%$, etc. We censored 172 observations, though only two in October 1993, that were higher in absolute value than $10 \%$. The mass point near $4.2 \%$ in October 1993 is the highest of all 15 6-month periods for a wide range of bin widths, although if we have bins that are wider than $2.5 \%$, the massing in October 1993 is blurred.
} 
Although the empirical evidence of massing at $4.2 \%$ seems clear, the choice of $4.2 \%$ is a puzzling one. The PMA's original request and most of the supporting documentation explicitly cite the Consumer Price Index as the inflation rate the companies would target. We have calculated the 12-month rolling average increases in the CPI through the end of 1993, and the increase in the CPI had not been over $4.0 \%$ since July 1991 . The only conceivably relevant number that is equal to $4.2 \%$ was the increase in the Producer Price Index for Pharmaceuticals during 1992, cited by the President of the PMA in an address to the organization and the press announcing the PMAs request to the DOJ on March 29, 1993 (see Mossinghoff, 1993). Note that we cannot formally test whether the companies were abiding by their pledges since we do not have information on their entire drug portfolio.

\section{Coordination in Transactions Prices}

The PMA's response explicitly identified the prices that would be subject to the agreement as "net prices," so we also consider evidence of coordination in our antibiotic transaction price data set. Histograms of price changes, similar to those in Figure 3, show evidence of some massing during the period around the six months when the DOJ was reviewing the PMA request, although nothing as clear as Figure 3. The first two columns of Table 4 report means and standard deviations in six-month price increases for the antibiotics, excluding those that were in the top $1 \%$ or bottom $1 \%$ of all price changes. Consistent with the evidence on the list prices, the standard deviation is lowest in the October 1993 period. We can reject that they are equal in all but two cases, April 1993, the period just before October 1993, and October 1995.0

Although the results on the transactions prices show some evidence of coordinated action by firms in the six months before October 1993, the results are not as stark as they are for the AWPs. In other words, the effects on price of successful coordination at the list price level seemed to be significantly dampened at the transactions price level. It is instructive to consider

\footnotetext{
${ }^{20}$ The third column of the table reports the p-values from F-tests of the equality of the variance in the sample period compared to the October 1993 period.
} 
why. One possibility is that firms believed that distorting the publicly-available AWPs was an effective way to diffuse political pressure, and that the eventual effect on transactions prices was not very important. They, then, could have distorted AWP but offered smaller discounts to their customers, thus not allowing those distortions to pass through to transactions prices. Another

possibility is simply that the mechanics of collective action are complicated in a market with so many products and so many purchasers, so genuine attempts by firms at collective action to limit price increases had less success when filtered through to the transactions level. A third possibility is that firms had routinely passed through different fractions of list price changes to transaction price changes, suggesting they may have understood that coordinating on list price changes would not show up as uniform changes in transaction prices.

\section{Coordinated Pricing and Political Sensitivity}

Just as we analyzed the relationship between a firm's political sensitivity and its other actions - making political contributions or price pledges - this section looks for a relationship between political sensitivity and the firm's likelihood of coordinating on price.

Our baseline model of price, or our model absent coordination, is that firms' price changes are a linear function of an index of covariates plus an additive error. These covariates are changes in variables which could affect the elasticity of demand for the drug, such as time before or after patent expiration. The covariates could also include measures of a firm's political sensitivity since they are factors which possibly influence pricing decisions. We designate the price increase implied by this model as the firm's "latent" price increase.

$$
\Delta \mathrm{p}_{\mathrm{ijt}}=\alpha+\beta \mathrm{X}_{\mathrm{ijt}}+\varepsilon_{\mathrm{ijt}}
$$

where $\Delta \mathrm{p}_{\mathrm{ijt}}$ is the change in price charged by firm $\mathrm{j}$ for drug $\mathrm{i}$ over half-year $\mathrm{t}$.

In addition, suppose certain firms engaged in coordinated pricing. In particular, they would price according to the model above unless their latent price increase exceeded an agreedupon limit, say a $4.2 \%$ increase. In that case, they would increase their prices $4.2 \%$. We hypothesize that the more politically sensitive firms would be more likely to coordinate. Define 
$\alpha_{\mathrm{it}}=1$ if the firm that produces drug $\mathrm{i}$ decides to coordinate in period $\mathrm{t}$ and increase prices by less than $4.2 \%$, and $\alpha_{\mathrm{it}}=0$ if the firm does not coordinate. If $\varepsilon_{\mathrm{ijt}} \sim \mathrm{N}\left(0, \sigma^{2}\right)$ then we can define the likelihood function as follows:

$$
\begin{aligned}
\mathrm{L} & =\prod_{\Delta \mathrm{p}_{\mathrm{it}}=4.2}\left[\alpha_{\mathrm{it}}\left(\Phi\left(\frac{\beta \Delta \mathrm{X}_{\mathrm{it}}-4.2}{\sigma}\right)\right)\right] \\
& \cdot \prod_{\Delta \mathrm{p}_{\mathrm{it}} \succ 4.2}\left[\left(1-\alpha_{\mathrm{it}}\right)\left(\sigma^{-1} \phi\left(\frac{\beta \Delta \mathrm{X}_{\mathrm{it}}-\Delta \mathrm{p}_{\mathrm{it}}}{\sigma}\right)\right)\right] \\
& \cdot \prod_{\Delta \mathrm{p}_{\mathrm{it}}<4.2}\left[\left(\sigma^{-1} \phi\left(\frac{\beta \Delta \mathrm{X}_{\mathrm{it}}-\Delta \mathrm{p}_{\mathrm{it}}}{\sigma}\right)\right)\right]
\end{aligned}
$$

We have omitted the term in the first line that would account for a firm happening to have $4.2 \%$ as its best response price increase. Based on the price distributions from before the coordination period, this is never more than one or two observations. We parameterize $\alpha$ as a function of

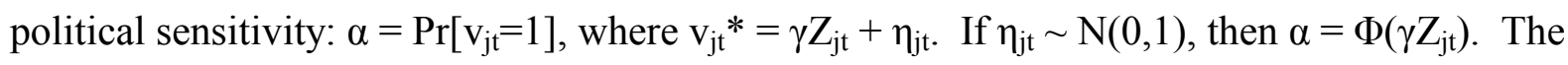
Z's are the two political sensitivity variables described above: Firm Patent Duration and Firm

Elder Drugs. Covariates for the latent pricing equation, the $\mathrm{X}^{\prime} \mathrm{s}$, include the time until each drug goes off patent (Time to Patent Exp.) and the time since it was off patent (Time Since Patent Exp.), as well as political sensitivity variables in some specifications. $\stackrel{22}{N e}$, therefore, allow political pressure to affect pricing in two ways, by changing a firm's latent price increase and by increasing the likelihood that a firm decides to coordinate pricing with other firms.

Results from estimating equation (4) using the AWP data for the top 106 drugs are presented in Table 5. The specifications in columns (1)-(3) are based on 6-month price changes during the coordination period (April to October 1993), while columns (4) and (5) are based on 6-month price changes to October 1992. We rounded price changes to the nearest tenth of a percent (this is the same rounding precision reflected in Figure 3), so a price change of $4.2 \%$

\footnotetext{
${ }^{21}$ This specification is very similar to one used by Knittel and Stango (2003).

${ }^{22}$ Caves et al. (1991) show that prices for drugs off patent have slower inflation (especially as they face more competition from generics) and that drug prices accelerate for the several years before a patent expires.
} 
effectively means the price change fell between $4.15 \%$ and $4.25 \%$.

The top half of the table presents coefficient estimates from the latent pricing equation, our model of how firms would price absent political pressure to coordinate. In columns (1) and (2) we do not include the political sensitivity variables in the pricing equation. When we add the two political sensitivity variables to the pricing equation in column (3), they are both statistically significant and suggest that firms with longer average patent durations and more elderly drugs increased prices faster. In other words, more sensitive firms were found actually to have higher latent price increases. Columns (4) and (5), estimated on data from 1992, also support this result. Firms with more elderly drugs continued to have higher latent price increases. It is possible that the coefficient on the Firm Patent Duration measure in column (3) reflects in part the high correlation between the firm-level variable and the drug level measures of time left on patent or time since patent expiration.

The bottom half of the table presents coefficient estimates from the coordination equation. In columns (1) and (2), we include the political sensitivity variables in the coordination equation one at a time. The estimates suggest that firms with longer average patent duration were no more likely to coordinate, but firms with more elder drugs were. In column (3), both political sensitivity variables are positive in the coordination equation. In other words, even though more politically sensitive firms had higher latent price increases, they were also more likely to coordinate.

While we would expect the latent pricing equation to be similar across years, we would expect starkly different results across years from the coordination equation, if the coordination was, in fact, a response to political pressure. This is precisely what we find. In column (4) we use the same coordination range as we used in columns (1)-(3), but since very few price changes were within that range, the coefficients on the variables in the coordination equation are very imprecisely estimated. In column (5) we expand the coordination range to $4.0-4.4 \%$. The coefficients on the firm-level variables in the coordination equation are negative and statistically significant, suggesting that the firms with high political sensitivity were actually less likely to use 
a price increase near $4.2 \%$ in 1992.

We did not estimate similar specifications on the antibiotic data since there is not a clear focal point in the data. Instead, we divided the antibiotic sample based on whether the manufacturing firm had an above-median value of Firm Patent Duration and then calculated the variance in pricing during the six-months ending October 1993 and the six months ending October 1992. We also divided the sample based on the manufacturing firm's value of Firm Elder Drugs. For both variables, the variance in 1993 was lower for the firms with abovemedian values of the political sensitivity variables, and the differences were both statistically significant (the p-values on the F-tests for equality were .007 and .023 for Firm Patent Duration and Firm Elder Drugs, respectively). In 1992, firms with above-median values of Firm Patent Duration had lower variance, but the firms with above-median values of Firm Elder Drugs had higher variance. This is consistent with the hypothesis that the more politically sensitive firms were more likely to coordinate on increases in their transaction prices in 1993.

\section{Conclusions}

The results presented here suggest that there was a political component to pharmaceutical pricing during the health care reform debates. In particular, the firms we identified as more politically sensitive, or vulnerable, were more likely to engage in coordinated pricing, consistent with a pledge many firms made not to raise prices more than the rate of inflation. While these firms coordinated on wholesale list prices of their drugs, the price distortion appears to have been dampened when filtered through to transactions prices, although the coordination seems to have had some effect. These actions are consistent with broad time series trends indicating sharp decreases in the rate of inflation in pharmaceuticals around the time of health care reform discussions.

Note that our results do not speak to the welfare implications of any politically motivated price reductions. It may be tempting to conclude that when firms voluntarily lower prices, efficiency increases. However, lower prices may reduce R\&D below socially optimal levels, favoring current drug consumers at the cost of the future sick. To the extent politics put 
downward pressure on prices in 1993-4, there is little evidence that the most affected companies have subsequently tried to make up with accelerated price increases. This suggests that the reallocation of rents to current consumers has not been temporary.

Our results raise, but do not answer, an interesting set of questions concerning the mechanics of coordination. The market for pharmaceuticals has multi-product firms who face many different types of consumers. Due to a government mandate, it also has publicly available list prices, and transactions prices are the result of negotiated discounts off of the list price. It is possible, of course, that the pharmaceutical firms were mostly interested in window-dressing, or the appearance of an industry-wide commitment to lower prices, and were less interested in actually coordinating, a strange reversal of the normal situation economists encounter. It is also possible, though, that actual coordination was the goal but that the mechanics of carrying out that coordination were hard to overcome. Although the small number of drugs, fifteen, that we have in common in our two data sets would make a more substantive analysis of these questions difficult, this setting offers an appealing potential for future work. 


\section{REFERENCES}

Baron, David P. 1997. "Integrated Strategy and International Trade Disputes: The Kodak-Fujifilm Case." Journal of Economics and Management Strategy 6 (Summer): 291-346.

Berndt, Ernst R., Iain M. Cockburn, Douglas L. Cocks, Arnold Epstein and Zvi Griliches. 1998. "Is Price Inflation Different for the Elderly? An Empirical Analysis of Prescription Drugs." In Alan Garber, editor, Frontiers of Health Policy. Cambridge, MA: The MIT Press.

Block, Michael K., Frederick C. Nold and Joseph G. Sidak. 1981. "The Deterrent Effect of Antitrust Enforcement." Journal of Political Economy 89 (June): 429-445.

Caves, Richard E., Michael D. Whinston and Mark A. Hurwitz. 1991. "Patent Expiration, Entry, and Competition in the U.S. Pharmaceutical Industry." Brookings Papers on Economics Activity: Microeconomics, 1-48.

Ellison, Sara F. 1998. "What Prices Can Tell Us About the Market for Antibiotics." Mimeo, MIT.

Ellison, Sara F. and Glenn Ellison. 1999. "Strategic Entry Deterrence And The Behavior Of Pharmaceutical Incumbents Prior To Patent Expiration.” Mimeo, MIT.

Ellison, Sara F. and Wallace P. Mullin. 2001. "Gradual Incorporation of Information: Pharmaceutical Stocks and the Evolution of President Clinton's Health Care Reform." Journal of Law and Economics 44 (April): 89-129.

Erfle, Stephen and Henry McMillan. 1990. "Media, Political Pressure, and the Firm: The Case of Petroleum Pricing in the Late 1970s." Quarterly Journal of Economics 105 (February): 115134.

Esty, Daniel C. and Richard E. Caves. 1983. "Market Structure and Political Influence: New Data on Political Expenditures." Economic Inquiry 21 (January): 24-38.

Federal Election Commission. 1994. Campaign Expenditures in the United States, 1978-1992: Longitudinal Political Action Committee (PAC) Data. Ann Arbor, MI: Inter-university Consortium for Political and Social Research (ICPSR).

Ferguson, John R. 1993. Letter to Honorable John W. Clark, Acting Assistant Attorney General, Antitrust Division, Re: Pharmaceutical Manufacturers Association, Request for Business Review Letter. March 12, 1993.

Fortune (1993). "Why Drug Prices Will Go Lower.” May 5, p. 56.

Glazer, Amihai and Henry McMillan. 1992. "Pricing by the Firm Under Regulatory Threat." Quarterly Journal of Economics 107 (August): 1089-1099. 
Grabowski, Henry G. and John M. Vernon. 1992. "Brand Loyalty, Entry and Price Competition in Pharmaceuticals after the 1984 Drug Act." Journal of Law and Economics 35 (October): 331-350.

Grier, Kevin B., Michael C. Munger and Brian E. Roberts. 1994. "The Determinants of Industry Political Activity, 1978-1986." American Political Science Review 88 (December): 911926.

Griliches, Zvi and Iain Cockburn. 1994. "Generics and New Goods in Pharmaceutical Price Indexes." American Economic Review 84 (December): 1213-1232.

Johnson, Haynes and David S. Broder. 1996. The System. Little, Brown and Company: Boston.

Kennedy, Peter W., Benoit Laplante, and John Maxwell. 1994. "Pollution Policy: The Role for Publicly Provided Information.” Journal of Environmental Economics \& Management 26 (January): 31-43.

Knittel, Christopher R. and Victor Stango. 2003. "Price Ceilings as Focal Points for Tacit Collusion: Evidence from Credit Cards.” American Economic Review 93 (December): 1703-1729.

Konar,Shameek and Mark A. Cohen. 1997. "Information as Regulation: The Effect of Community Right to Know Laws on Toxic Emissions.” Journal of Environmental Economics and Management 32 (January): 109-24.

Makinson, Larry and Joshua Goldstein. 1994. Open Secrets: The Encyclopedia of Congressional Money \& Politics. $3^{\text {rd }}$ Edition. Washington, D.C.: Congressional Quarterly.

Masson, Alison and Robert L. Steiner. 1985. Generic Substitution and Prescription Prices: Economic Effects of State Drug Product Selection Laws. Washington, D.C.: Federal Trade Commission, Bureau of Economics.

Masters, Marick F. and Gerald D. Keim. 1985. "Determinants of PAC Participation Among Large Corporations." Journal of Politics 47 (November): 1158-1173.

Maxwell, John W., Thomas P. Lyon and Steven C. Hackett. 2000. "Self-Regulation and Social Welfare: The Political Economy of Corporate Environmentalism." Journal of Law and Economics 43 (October): 583-617.

Mossinghoff, Gerald J. 1993. "Address to the PMA Annual Meeting," Boca Raton Resort and Club, Boca Raton, Florida, March 29, 1993.

Noll, Roger G. 1989. "The Politics of Regulation." In Richard Schmalensee and Robert Willig, eds., Handbook of Industrial Organization, New York: North Holland. 
Olmstead, Alan L. and Paul Rhode. 1985. "Rationing without Government: The West Coast Gas Famine of 1920.” American Economic Review 75 (December): 1044-55.

Porter, Robert H. and J. Douglas Zona. 1999. "Ohio School Milk Markets: An Analysis of Bidding.” RAND Journal of Economic 30 (Summer): 263-88.

. 1993. "Detection of Bid Rigging in Procurement Auctions." Journal of Political Economy 101 (June): 518-38.

The Pink Sheet (1993a). "Merck is Courting Administration with Proposal to Limit Pharmaceutical Price Rises." 55(6): 10-12.

The Pink Sheet (1993b). "In Brief.” 55(12): 2.

The San Francisco Chronicle (1993). "Drug Firms' Proposal For Holding Prices Down.” March 13, p. A5.

Scott Morton, Fiona. 1997. "The Strategic Response by Pharmaceutical Firms to the Medicaid Most-Favored-Customer Rules." RAND Journal of Economics 28 (Summer): 269-290.

Stango, Victor. 2000. "Strategic Responses to Regulatory Threat in the Credit Card Market." Mimeo, University of Tennessee.

Stigler, George. 1971. "The Theory of Economic Regulation." Bell Journal of Economics 2 (Spring): 3-21.

The Wall Street Journal (1991). "Merck's Chairman Blames Price Rises on Industry Rivals." November 8, p. B2A. 
Table 1: Summary Statistics, Pricing Data

\begin{tabular}{|c|c|c|c|c|c|}
\hline Data Set & Variable & Varies by & Mean & $\begin{array}{c}\text { Standard } \\
\text { Deviation }\end{array}$ & $\begin{array}{c}\text { Number of } \\
\text { Obs. }\end{array}$ \\
\hline \multicolumn{6}{|c|}{ Top 106 Drugs (AWP) } \\
\hline \multirow[t]{3}{*}{$(4 / 89-10 / 96)$} & $\begin{array}{l}\text { Price Change } \\
\text { [percent] }\end{array}$ & $\begin{array}{l}\text { Presentation- } \\
\text { half year }\end{array}$ & 2.17 & 3.40 & 7263 \\
\hline & $\begin{array}{l}\text { Time to Patent Exp. } \\
\text { [years] }\end{array}$ & Drug-half year & 5.04 & 4.96 & 1025 \\
\hline & $\begin{array}{l}\text { Time Since Patent Exp. } \\
\text { [years] }\end{array}$ & Drug-half year & .64 & 1.44 & 1025 \\
\hline \multicolumn{6}{|c|}{ Antibiotics (Transaction Prices) } \\
\hline$(10 / 90-4 / 96)$ & $\begin{array}{l}\text { Price Change } \\
\text { [percent] }\end{array}$ & Drug-half year & .26 & 11.0 & 1830 \\
\hline
\end{tabular}


Table 2: Antibiotics Prices across AWP and Transaction Price Data Sets

\begin{tabular}{|c|c|c|}
\hline & \multicolumn{2}{|c|}{ Six-month price changes } \\
\hline \multicolumn{3}{|l|}{ AWP } \\
\hline Mean [percent] & \multicolumn{2}{|c|}{1.54} \\
\hline Standard Deviation & \multicolumn{2}{|c|}{3.42} \\
\hline Number of Observations & \multicolumn{2}{|c|}{154} \\
\hline \multicolumn{3}{|l|}{ Transaction Prices } \\
\hline Mean [percent] & \multicolumn{2}{|c|}{.20} \\
\hline Standard Deviation & \multicolumn{2}{|c|}{3.63} \\
\hline Number of Observations & \multicolumn{2}{|c|}{154} \\
\hline \multicolumn{3}{|c|}{ Correlation between AWP \& Transaction Price Changes by Channel } \\
\hline & Overall & Within Drug \\
\hline$\sigma_{\mathrm{AWP}, \text { Transaction-Federal }}$ & .23 & .18 \\
\hline$\sigma_{\mathrm{AWP}, \text { Transaction-Clinics }}$ & .29 & .23 \\
\hline$\sigma_{\mathrm{AWP}, \text { Transaction-HMOs }}$ & .32 & .24 \\
\hline$\sigma_{\mathrm{AWP}, \text { Transaction-Hospitals }}$ & .57 & .48 \\
\hline$\sigma_{\mathrm{AWP}, \text { Transaction-Drugstores }}$ & .72 & .66 \\
\hline$\sigma_{\mathrm{AWP}, \text { Transaction-All Channels (unweighted) }}$ & .79 & .73 \\
\hline
\end{tabular}


Table 3: Company-Specific Political Sensitivity

\begin{tabular}{|c|c|c|c|c|}
\hline \multirow{3}{*}{$\begin{array}{l}\text { Company } \\
\text { Abbott Labs }\end{array}$} & \multicolumn{2}{|c|}{ Independent Variables } & \multicolumn{2}{|c|}{ Other Measures } \\
\hline & $\begin{array}{c}\text { Firm Patent } \\
\text { Duration } \\
\text { (years) }\end{array}$ & $\begin{array}{c}\text { Firm Elder } \\
\text { Drugs } \\
\text { (percent) }\end{array}$ & $\begin{array}{c}\text { Growth in } \\
\text { Company } P A C \\
\text { (percent } \Delta \text { ) }\end{array}$ & Price Pledge? \\
\hline & $10.0 \quad(\mathrm{H})$ & $34 \quad(\mathrm{H})$ & $18 \quad(\mathrm{H})$ & 3 \\
\hline Amgen & $20.0 \quad(\mathrm{H})$ & $0 \quad(\mathrm{~L})$ & $396(\mathrm{H})$ & $\mathrm{N}$ \\
\hline Bayer & $8.7 \quad(\mathrm{H})$ & $13 \quad(\mathrm{~L})$ & NA & $\mathrm{N}$ \\
\hline Bristol-Myers Squibb & $4.4 \quad(\mathrm{~L})$ & $66 \quad(\mathrm{H})$ & $-7 \quad(\mathrm{~L})$ & 3 \\
\hline Burroughs Wellcome & $5.4 \quad(\mathrm{H})$ & $0 \quad(\mathrm{~L})$ & $-44 \quad(\mathrm{~L})$ & $\mathrm{N}$ \\
\hline Eli Lilly & $5.5 \quad(\mathrm{H})$ & $17 \quad(\mathrm{~L})$ & $-30 \quad(\mathrm{~L})$ & 3 \\
\hline G.D. Searle & $3.7 \quad(\mathrm{~L})$ & $51 \quad(\mathrm{H})$ & $69 \quad(\mathrm{H})$ & 3 \\
\hline Genentech & $3.8 \quad(\mathrm{~L})$ & $54 \quad(\mathrm{H})$ & $-32 \quad(\mathrm{~L})$ & 3 \\
\hline Glaxo & $4.9 \quad(\mathrm{H})$ & 11 (L) & $86 \quad(\mathrm{H})$ & 2 \\
\hline Hoechst-Roussel & $2.1 \quad(\mathrm{~L})$ & $32 \quad(\mathrm{H})$ & NA & 3 \\
\hline Hoffmann-La Roche & $8.7 \quad(\mathrm{H})$ & $0 \quad(\mathrm{~L})$ & $46 \quad(\mathrm{H})$ & 2 \\
\hline Johnson \& Johnson & $11.2 \quad(\mathrm{H})$ & $0 \quad(\mathrm{~L})$ & $181 \quad(\mathrm{H})$ & 3 \\
\hline Marion Merrell Dow & $0.4 \quad(\mathrm{~L})$ & $65 \quad(\mathrm{H})$ & $8 \quad(\mathrm{~L})$ & 2 \\
\hline Merck & $7.1 \quad(\mathrm{H})$ & $58 \quad(\mathrm{H})$ & $48 \quad(\mathrm{H})$ & 1 \\
\hline Pfizer & $6.4 \quad(\mathrm{H})$ & $61 \quad(\mathrm{H})$ & $48 \quad(\mathrm{H})$ & 2 \\
\hline SmithKline Beecham & $8.3 \quad(\mathrm{H})$ & $17 \quad(\mathrm{~L})$ & $18 \quad(\mathrm{H})$ & 3 \\
\hline Sandoz & $4.2 \quad(\mathrm{~L})$ & $21 \quad(\mathrm{~L})$ & $130 \quad(\mathrm{H})$ & $\mathrm{N}$ \\
\hline Schering-Plough & $4.3 \quad(\mathrm{~L})$ & $15 \quad(\mathrm{~L})$ & $8 \quad(\mathrm{~L})$ & $\mathrm{N}$ \\
\hline Syntex & $1.5 \quad(\mathrm{~L})$ & $100 \quad(\mathrm{H})$ & $9 \quad(\mathrm{~L})$ & 3 \\
\hline Upjohn & $0.8 \quad(\mathrm{~L})$ & $34 \quad(\mathrm{H})$ & $-50 \quad(\mathrm{~L})$ & 3 \\
\hline Warner-Lambert & $1.8 \quad(\mathrm{~L})$ & $66 \quad(\mathrm{H})$ & $-4 \quad(L)$ & 3 \\
\hline Wyeth-Ayerst & $2.1 \quad(\mathrm{~L})$ & $30 \quad(\mathrm{~L})$ & $-11(\mathrm{~L})$ & 2 \\
\hline Zeneca & $6.6 \quad(\mathrm{H})$ & $81 \quad(\mathrm{H})$ & NA & 3 \\
\hline MEAN & 5.7 & 36 & 44 & \\
\hline STD DEVIATION & 4.3 & 29 & 101 & \\
\hline
\end{tabular}

Note: We used the following codes in the Price Pledge column: '1' if the company made a pledge in 1990, '2' if the company had made a pledge by March 1993, '3' if the company made a pledge at any time after March 1993 and 'N' if we have no indication that the company pledged. 
Table 4: Distribution of Antibiotic Price Changes

\begin{tabular}{lcccc}
\hline & Mean & Standard Deviation & $\boldsymbol{P}$-value $^{I}$ & $\boldsymbol{N}^{\mathrm{I}}$ \\
\hline $\begin{array}{l}\text { Six-month price } \\
\text { changes to: }\end{array}$ & & & \\
$\quad$ October 1991 & 1.64 & 8.67 & $<.001$ & 172 \\
April 1992 & 1.08 & 8.63 & $<.001$ & 170 \\
October 1992 & -.46 & 8.22 & $<.001$ & 171 \\
April 1993 & .30 & 5.82 & .904 & 177 \\
October 1993 & .10 & 5.76 & & 181 \\
April 1994 & -.51 & 6.60 & .069 & 183 \\
October 1994 & -.21 & 6.69 & .046 & 184 \\
April 1995 & -.72 & 6.94 & .013 & 185 \\
October 1995 & -.40 & 6.26 & .266 & 185 \\
April 1996 & -.86 & 6.84 & .022 & 185 \\
& & & & \\
\hline
\end{tabular}

${ }^{1}$ The p-value is from an F-test of the null hypothesis that the variance of price changes in the period is equal to the variance of price changes to October 1993. 
Table 5: Propensity to Coordinate by Firm-Top 106 Drugs

\begin{tabular}{|c|c|c|c|c|c|}
\hline & (1) & (2) & (3) & (4) & (5) \\
\hline \multicolumn{6}{|l|}{ Pricing Equation } \\
\hline Years to Patent Exp. & $\begin{array}{l}.012 \\
(.019)\end{array}$ & $\begin{array}{l}.012 \\
(.019)\end{array}$ & $\begin{array}{l}-.025 \\
(.025)\end{array}$ & $\begin{array}{l}.017 \\
(.026)\end{array}$ & $\begin{array}{l}.018 \\
(.028)\end{array}$ \\
\hline Years since Patent & $-.274^{* *}$ & $-.274^{* *}$ & $-.192^{* *}$ & -.156 & -.166 \\
\hline Exp. & $(.066)$ & $(.066)$ & $(.067)$ & $(.090)$ & $(.097)$ \\
\hline Firm Patent Duration & & & $\begin{array}{l}.151^{* *} \\
(034)\end{array}$ & $\begin{array}{l}-.008 \\
(037)\end{array}$ & -.018 \\
\hline Firm Elder Drugs & & & $\begin{array}{l}1.96^{* *} \\
(.36)\end{array}$ & $\begin{array}{l}2.23^{* *} \\
(.38)\end{array}$ & $\begin{array}{l}2.03^{* *} \\
(.41)\end{array}$ \\
\hline \multicolumn{6}{|l|}{$\begin{array}{l}\text { Coordination } \\
\text { Equation }\end{array}$} \\
\hline Firm Patent Duration & $\begin{array}{l}-.014 \\
(.033)\end{array}$ & & $\begin{array}{l}.055 \\
(.038)\end{array}$ & $\begin{array}{l}1.88 \\
(25.7)\end{array}$ & $\begin{array}{l}-.128^{*} \\
(.063)\end{array}$ \\
\hline Firm Elder Drugs & & $\begin{array}{l}2.41^{* *} \\
(.67)\end{array}$ & $\begin{array}{l}2.83^{* *} \\
(.73)\end{array}$ & $\begin{array}{l}-44.5 \\
(863)\end{array}$ & $\begin{array}{c}-4.47^{* *} \\
(.67)\end{array}$ \\
\hline $\boldsymbol{\sigma}$ & $\begin{array}{l}2.13^{* *} \\
(.06)\end{array}$ & $\begin{array}{l}2.13^{* *} \\
(.06)\end{array}$ & $\begin{array}{l}2.07^{* *} \\
(.06)\end{array}$ & $\begin{array}{l}2.11^{* *} \\
(.06)\end{array}$ & $\begin{array}{l}2.24^{* *} \\
(.07)\end{array}$ \\
\hline $\begin{array}{l}\Delta p \_6-m o n t h \text { to: } \\
\text { N }\end{array}$ & $\begin{array}{l}\text { Oct. } 1993 \\
663\end{array}$ & $\begin{array}{c}\text { Oct. } 1993 \\
663\end{array}$ & $\begin{array}{c}\text { Oct. } 1993 \\
663\end{array}$ & $\begin{array}{l}\text { Oct. } 1992 \\
584\end{array}$ & $\begin{array}{l}\text { Oct. } 1992 \\
584\end{array}$ \\
\hline
\end{tabular}

Standard errors in parentheses. $*$ significant at $5 \% ; * *$ significant at $1 \%$ Columns (1)-(4) define coordination as increasing prices by $4.15 \%-4.25 \%$. Column (5) defines coordination as increasing prices by $4.0 \%-4.4 \%$. 


\begin{abstract}
APPENDIX
Following is a more detailed description of some of the data sets and variables used in this paper.
\end{abstract}

\title{
Prices
}

The first pricing data set, with the top 106 largest revenue drugs, was derived from the ReadyPrice database, a compendium of the information found in the annual publication and monthly

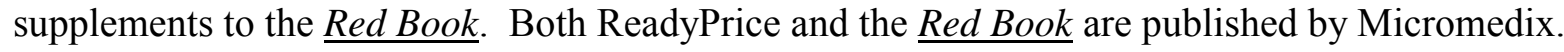
ReadyPrice contains average wholesale prices (AWP) for a number of drugs, of which we have selected 106 to analyze in this paper. Our data set covers only those NDCs that were available in the beginning of 1997, and the pricing histories for each NDC are not consistent. Only 52 percent of the NDCs for which we have data in 1997 are covered in 1989. Information on historical pricing is unavailable because the NDC was introduced mid-way through the time period we study, or because Ready Price discontinued coverage of the NDC.

One concern with the ReadyPrice series is that it does not contain information on sales or revenue figures by NDC. We are unable to identify those NDCs that are used by many customers and those which are comparatively rare. (It is not entirely clear that we should weight more heavily drugs or dosage-forms used by more people. Dosage-forms used by more people are seen by more people, but it is not clear that this is the relevant metric of political exposure.) The difference between the standard deviation within a drug-month and between drug-months suggests that the bulk of the variation is between drug-months, though price changes are not uniform across NDCs within a drug. We report results using each NDC as a separate observation.

The second pricing data set, with information on transaction prices and volume sold for antibiotics, covers October 1990 to September 1996. These data are monthly and come at the NDC level, but we aggregate up to the drug level by computing a Divisia price index for each drug. See Ellison (1998) for a more comprehensive discussion both of this data set and the calculation of the Divisia indexes.

There are 15 drugs common to both data sets, and we present summary statistics on this subset in Table 2. The common drugs are: Amoxil Augmentin Biaxin Ceclor Ceftin Cipro Claforan Cleocin Duricef Fortaz Minocin Primaxin Rocephin Vancocin Zithromax.

\section{Firm Patent Duration}

Firm Patent Duration measures the sales-weighted average patent life remaining on each company's drug portfolio as of 1993. To calculate this variable, we used information on sales by drug and patent lives. It is difficult to find sales information for a number of drugs in comparable markets (e.g. U.S. and not international, consistent weights on distribution outlets). We use the annual lists of the top 100 drugs by US sales published every spring in Med Ad News. Because we want to describe a company's perspective in 1993, we use information on drug sales in 1993, 1994 and 1995, under the assumption that companies could accurately forecast drug sales for existing and new products through 1995. The three lists together cover 140 drugs. Each list contains information on the current year's sales as well as the previous years', so a number of the gaps in sales figures could be filled. For instance, when a drug showed up on the 1994 list that had not been on the 1993 list, the 1994 list almost always contained information on 1993 sales. For observations where sales figures 
were still missing, we identifies several cases where the drug was not yet in the US market, and for the remaining observations, we extrapolated from recent growth rates. We calculate each drug's total sales over the three-year period, though we discount 1994 and 1995 sales by factors of .9 and .8 respectively because, as of 1993, the sales were both in the future and uncertain.

We used the patent expiration years reported in Med Ad News or Scripps. The commerciallyrelevant expiration date is not always identifiable in the FDA's Approved Drug Products with Therapeutic Equivalence Evaluations (also referred to as the Orange Book), though the expiration dates in the Orange Book coincide with the commercial sources (plus or minus two years) about 90 percent of the time. We calculate the number of years each drug has remaining on patent and then take the sales-weighted average across each company's products.

Since we only consider drugs that made the top 100 lists in 1993-1995, we do not have a complete view of each company's patent profile. The distortions this introduces, however, are most likely minimal. First, drug sales are skewed heavily towards the most popular drugs. (For instance, 1993 US sales for Zantac, the top selling drug according to Med Ad, were 70 times larger than sales for the one-hundredth largest drug.) Also, for 20 of the 23 companies in our study, the largest drug not making the Med Ad lists would comprise less than five percent of total sales. Of course, if companies have a number of small drugs that do not make the list, and if those drugs are very different from the ones on the list (in terms of remaining patent years), the political sensitivity measures are less accurate. We do not think this is the case, though, since comparing the drugs we have on our list to the drugs mentioned by companies in their annual reports and 10K's suggests we have covered the bulk of the important ones.

\section{Firm Elder Drugs}

Firm Elder Drugs measures the percent of each company's revenue from drugs in therapeutic classes that are predominantly used by the elderly. The drugs considered for each company and the sales weights used are identical to those described above. Elderly therapeutic classes are identified from Berndt et al. (1998) who report usage patterns between the elderly and non-elderly based on information from surveys of physicians on drugs prescribed to patients of different ages. All cardiac drugs, antineoplastic agents, cholesterol reducers, antidiabetics, arthritis treatments, glaucoma treatments, antiemetics, diuretics, clot dissolvers, and one drug (Parlodel) used to treat patients with Parkinson's disease were considered elderly.

\section{Growth in Company PAC}

Growth in Company PAC measures the increase in the annual disbursements made by each company's corporate PAC between the 1991/2 election cycle and calendar year 1993. Information on PAC disbursements for the 1991/2 election cycle is from Makinson and Goldstein (1994). The PACs of two companies, Amgen and Wyeth-Ayerst, were not covered by Makinson and Goldstein (1994), so we used information assembled by ICPSR. Data on PAC disbursements for companies covered by both Makinson and Goldstein and ICPSR were very similar. Information on PAC disbursements for the calendar year 1993 was obtained directly from company filings with the Federal Election Committee, downloaded from the Federal Election Commission's web site (www.fec.gov). Online information only extends back to 1993. Note that Makinson and Goldstein (1994) only covers donations to Congressional candidates, so even though 1991/2 coincided with the 
presidential election cycle, the PAC contributions we consider are roughly comparable across time periods.

\section{Price Pledge?}

We gathered information on the timing and existence of company price pledges from reports in the trade press and from a March 14, 1996 FTC document concerning an investigation of the pledge as a means of price fixing. Numerous articles discuss Merck's pledge in 1990 (see, for example, The Pink Sheet, 1993b). In the PMA's request to the DOJ for antitrust exemption to oversee adherence to price pledges, the PMA states that ten companies had already made pledges but does not identify which companies fell into that category. We identified nine companies that had pledged by February 1993 (including Merck) from the trade press (see The Pink Sheet, 1993a) although three of the nine companies are not in our data set. We identified companies as late pledgers, category 3, if they were not identified in The Pink Sheet (1993a) but were identified on the 1996 FTC document.

\section{Time to/since Patent Exp.}

To construct the last two variables in Table 1, Time to Patent Expiration and Time since Patent Expiration, we use the patent expiration years described above. The first variable is equal to zero in years after a drug's patent has expired and equal to the number of years until the patent expires for drugs that are still on patent. The second variable is equal to zero for drugs that still have patent coverage and equal to the number of years since the patent expired for off-patent drugs. Due to the different regulatory treatment of antibiotics, patent expirations are not available from the same sources. For the second data set, therefore, we simply use the year in which generics entered as the year of commercially-relevant patent expiration. 
Figure 1

Changes in Prices or Indexes, December to December

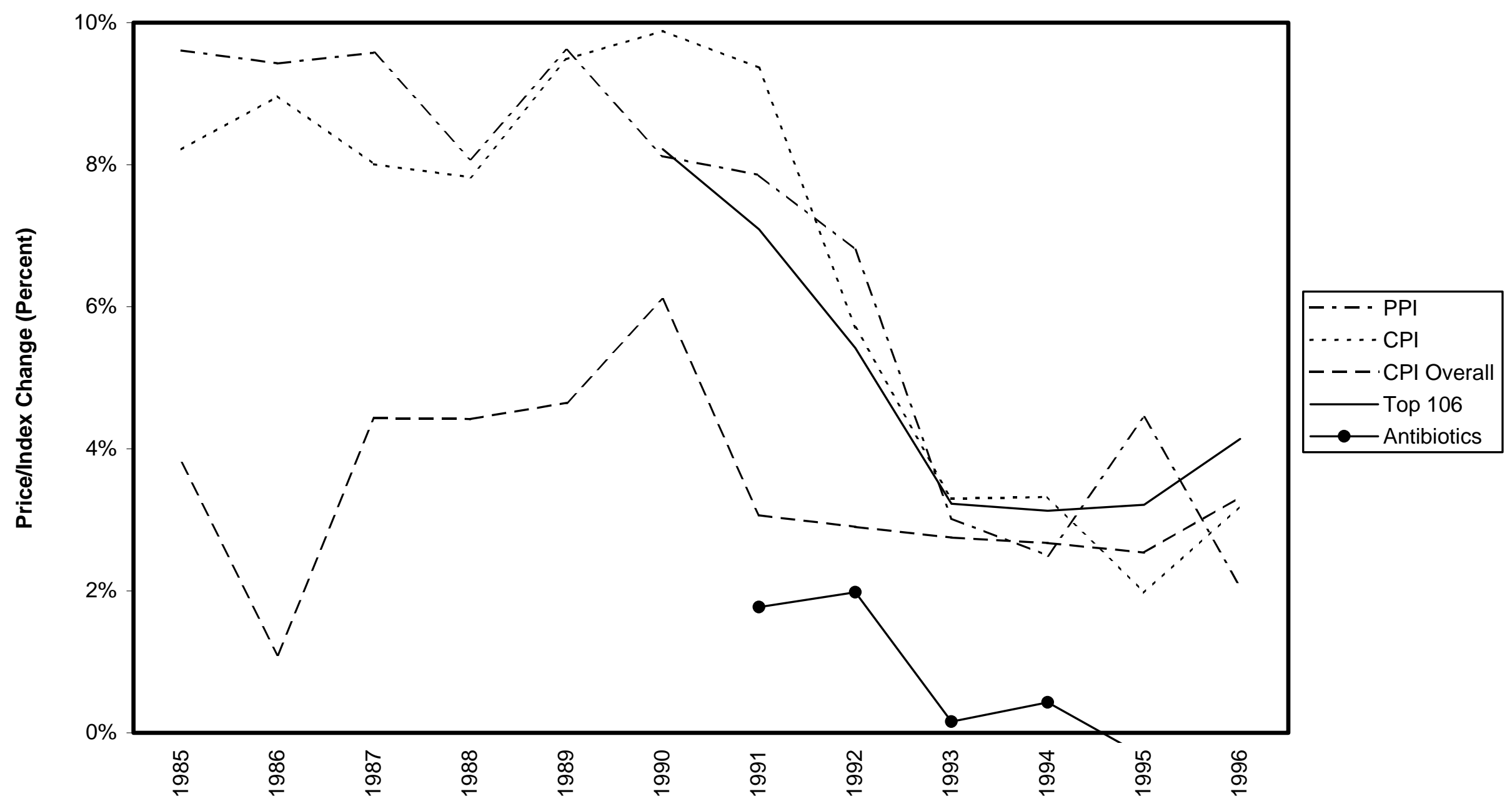




\section{Figure 2}

R\&D Expenditure as a Percent of Sales by Sample Companies

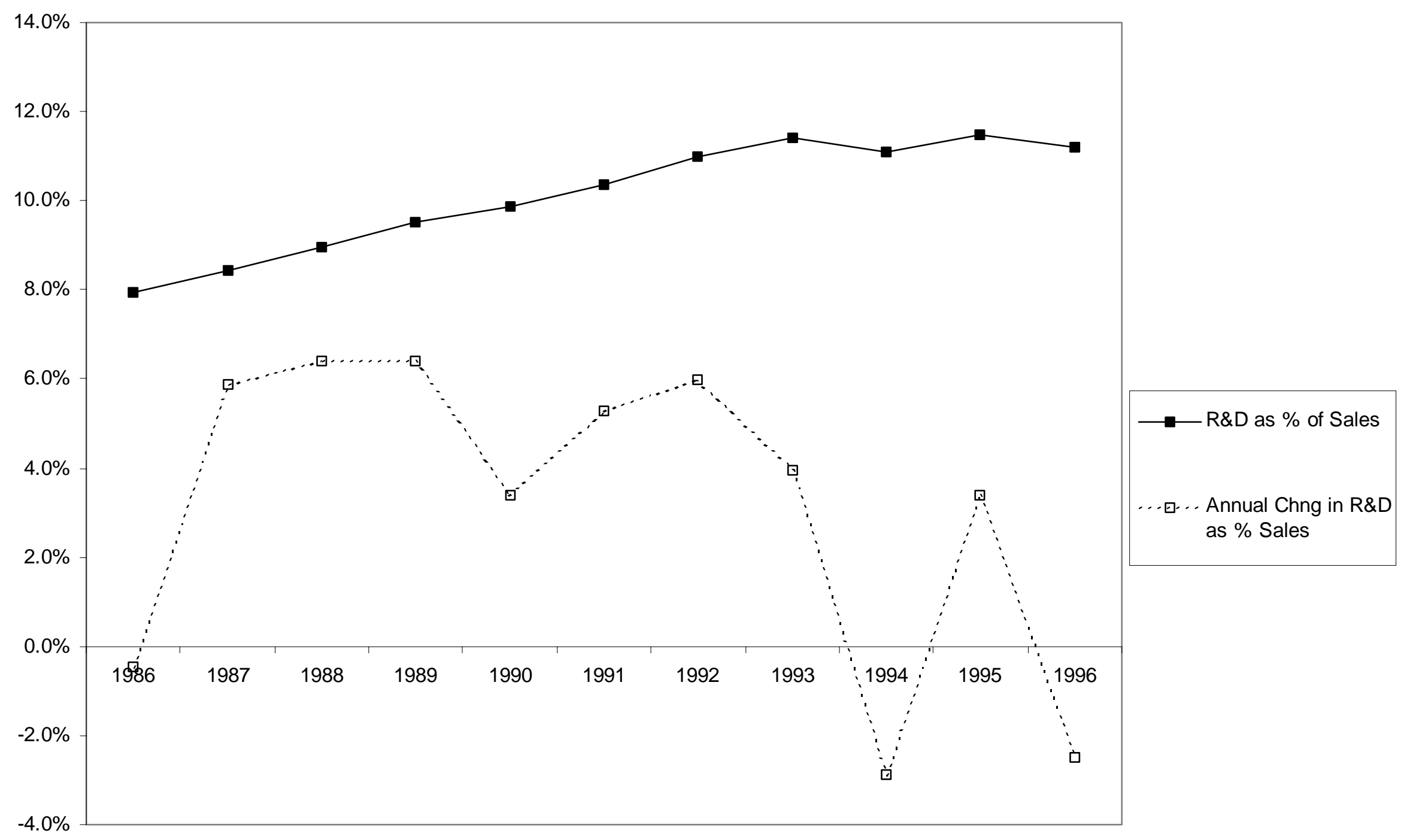




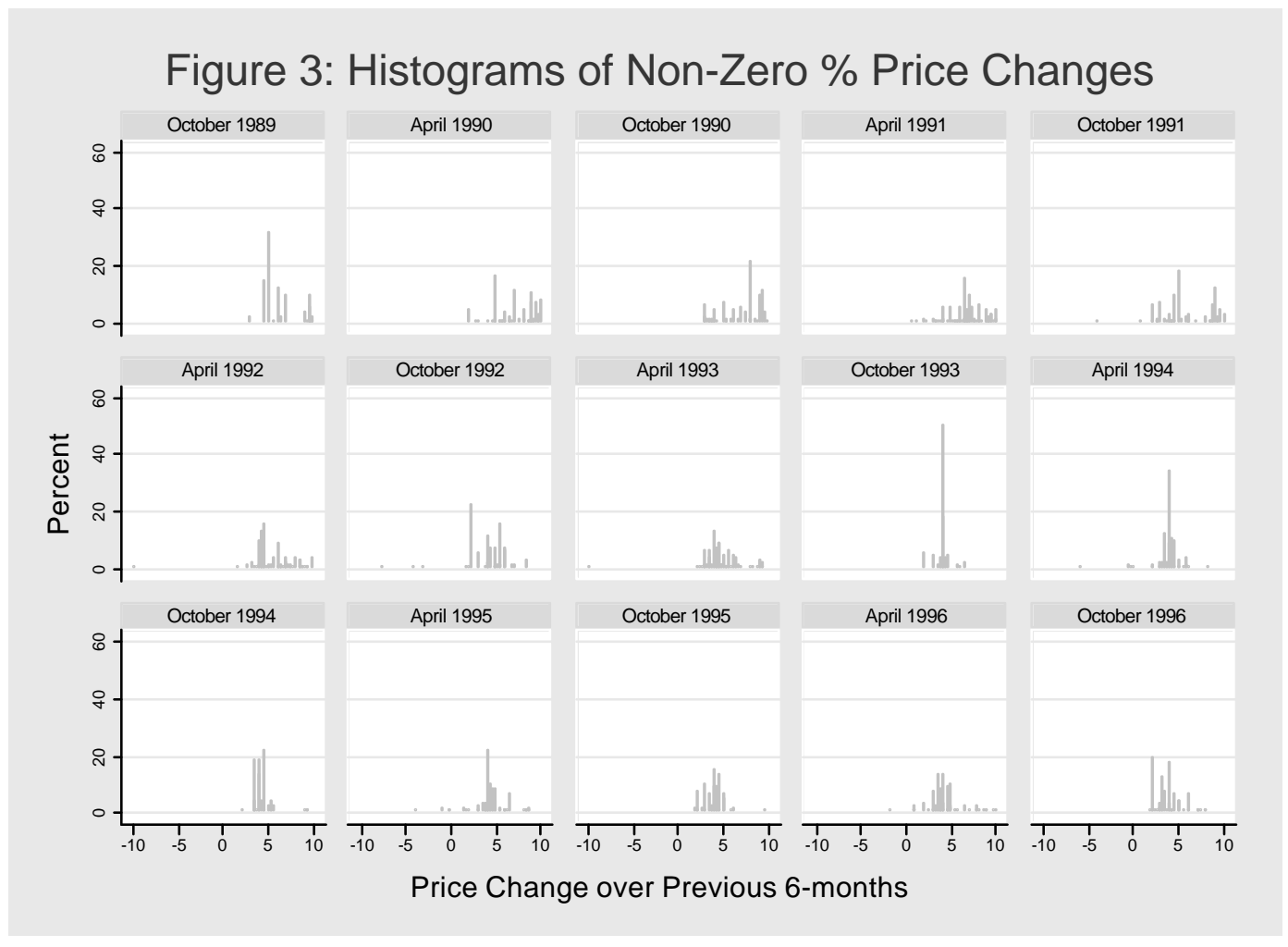

